\title{
A Literature Review of the Predictive Validity of European Dental School Selection Methods
}

Corresponding author mail id :-c.cunningham@abdn.ac.uk

Claudia Cunningham, Aberdeen Dental Institute, University of Aberdeen, Scotland, UK Fiona Patterson, Work Psychology Group, Derby, UK

Jennifer Cleland, Centre for Healthcare Research and Innovation (CHERI), University of Aberdeen, Scotland, UK

\section{Abstract}

Introduction

Selection to dental school is the point at which there is the potential to assess a wide range of candidate attributes and select those most likely to learn, train and work within the profession. Despite this, little is known in terms of what works and what does not work in dental selection in terms of predicting future performance accurately and fairly. Given this, our aim was to synthesize the last 30 years of research investigating the predictive validity of dental school selection methods.

\section{Methods}

A search of the electronic databases SCOPUS, Pubmed and Embase was conducted. Results were limited to English language studies published between January 1987 and January 2017.

This article has been accepted for publication and undergone full peer review but has not been through the copyediting, typesetting, pagination and proofreading process, which may lead to differences between this version and the Version of Record. Please cite this article as doi: $10.1111 /$ eje. 12405

This article is protected by copyright. All rights reserved. 
Results

21 studies were included. Selection tools fell into five broad categories: tests of personal qualities; cognitive ability; academic attainment; psychomotor skills and combined ability tests. Most were retrospective, single site studies limited to early years of dental school. Weak correlations were reported but in most cases these were between small sections of the selection tool and/or the outcome measure.

\section{Discussion}

There was a notable dearth of published research examining dental schools selection processes across Europe over the last 30 years. Current literature was limited by weak study design and lack of long term follow up.

\section{Conclusion}

There is insufficient high quality evidence from which to draw any conclusions as to the best selection methods to use in dental school selection. Without this, designing selection frameworks for dentistry which are appropriately weighted, reliable and valid remains a challenge.

\section{Introduction}

Selection to dental school is the point at which there is the potential to assess a wide range of candidate attributes and select those most likely to learn, train and work within a profession for which they have a particular aptitude ${ }^{1}$. Once admitted to dental school approximately $98 \%$ of students graduate and work as dentists ${ }^{2,3}$. Selection and dental school training thus appears to be effective at getting students to the point of graduation and early career posts. However evidence of effectiveness of selection in terms of selecting dentists who continue to make a positive contribution to their profession and the public they serve after graduation is less convincing ${ }^{4}$.

A scoping exercise indicated that within Europe prior academic attainment, used either in isolation or in combination with a personal statement, references and interviews, remains the main method of admission to dental school ${ }^{5-24}$. This is in contrast to countries such as the USA ${ }^{25}$, Canada $^{26}$ and Australia ${ }^{27}$ who typically use a dental admissions test. More contemporary approaches still depend on prior academic attainment (usually performance on school examinations) as the first hurdle in the admissions process, but this may be followed by an admissions test, an interview and/or a manual dexterity test ${ }^{28-35}$. This reflects that seen in medical selection ${ }^{36,37}$ but, unlike medicine - and indeed higher education as a whole ${ }^{38-41}$, selection, while a topic of discussion within dental education ${ }^{42-44}$, does not appear to be a major area of research activity within Europe. As a consequence, little is known in terms of what works and what does not work in dental selection in terms of predicting future performance accurately and fairly ${ }^{45}$. This leaves dental schools open to criticism, and often unable to reassure key stakeholders that their approaches to selection do indeed selecting the "best" applicants.

A core concept in determining the effectiveness of a selection method is the validity of the selection tool. The concept of validity was formulated by Kelley ${ }^{46}$ who stated that a test is valid if it measures what it claims to measure. For a brief overview of the different types of validity see table 1.

This article is protected by copyright. All rights reserved. 
Predictive validity is the ability of a test or intervention to predict future performance and is therefore appropriate to examine in relation to whether or not dental school selection is effective ${ }^{47}$.

We present here a synthesis of the results of the last 30 years of research investigating the predictive validity of dental school selection methods in Europe. Our aim in doing so is to inform future practice in dental student selection and outline a future research agenda.

\section{Methods}

This review was conducted in accordance to the PRISMA guidelines for systematic reviews ${ }^{48}$. A search of the electronic databases SCOPUS, Pubmed and Embase was conducted in January 2017 using the MeSH terms 'Education', 'Dental', 'Criteria' and 'school admission' and equivalent free text searches for terms pertaining to dental education (school, university), criteria (methods, tools) and admission (selection, entrance). Further papers were also identified upon reading the full text of studies found in the electronic search. A flow diagram showing the process of investigation can be viewed at Figure 1.

\section{Study selection}

Results were limited to English language studies published in the 30 years between January 1987 and January 2017. Peer-reviewed papers and studies reporting empirical data relating to undergraduate dental education in Europe were included. We excluded non-European studies, general opinion pieces, commentaries and letters. The context for our exclusion criteria can be viewed in box 1 .

\section{Assessment of studies}

All included studies were assessed first by CC and then collectively by all three authors. Study assessment included appraisal of study quality. Any disagreements were resolved by discussion.

Included papers were assessed with regards to: (1) selection method assessed (e.g. interview, aptitude test) and (2) study design (e.g., study type, site, population, statistical analysis and outcome measure). This data collection protocol was a modified version of that employed by a similar review of medical school selection criteria ${ }^{37}$. A synthesis of the findings is provided below.

\section{Data synthesis}

On completion of the systematic search, it was apparent that the diverse nature of the study designs and outcome measures used would not lend themselves to a traditional systematic review. Several conditions are critical to sound meta-analysis or systematic review ${ }^{49}$. The diversity of the selection methods, combination of methods, their application and different outcome measures meant studies could not be combined in any meaningful way ${ }^{50}, 51,52$. Thus, a narrative synthesis was the most appropriate way to synthesize the data. Narrative synthesis is a systematic process of making sense of evidence using a range of methods which relies primarily on the use of words and text to summarise and explain data ${ }^{53}$.

\section{Results}

The search strategy yielded a total of 206 citations after the removal of duplicates. Following exclusion of studies that did not meet inclusion criteria, 21 studies remained. A summary table of the results can be view in Table 2. The results are presented under the following subsections:

This article is protected by copyright. All rights reserved. 
general findings; selection tool used and predictive validity; research design used to validate selection practices; and outcome measures.

\section{General Findings}

The last 10 years yielded the highest rate of publication $(n=14)^{5,28-34,54-59}$ while half as many (7) studies were published between 1997 and 2007 $35,60-65$. Most papers were from the UK $(n=9)^{5,28,29,34,58,59,62,64,65}$ and reported studies from six different dental schools. Sweden provided four studies from two institutions ${ }^{30,35,61,63}$, whilst the remaining studies were from Austria $(n=2)^{33,54}$, Belgium $(n=2)^{32,56}$, Germany $(n=2)^{31,55}$, Ireland $(n=1)^{60}$ and Italy $(n=1)^{57}$.

\section{Outcome measures}

Outcome measures varied significantly across all papers. Most authors used existing dental school assessments as an outcome measure , $28-31,54,55,58,59$ and these were individual to each school. No detail was given in any of the papers as to the nature of these assessments, or their robustness in terms of psychometric properties ${ }^{66}$. The majority of authors assessed if their selection methods predicted performance on knowledge -based exams ${ }^{5,28-35,54-56,58-60,64,65}$ regardless of whether the selection method was designed to measure academic attainment, or not (for example, comparing performance on psychomotor skills test with performance on a later knowledge-based exam). Table 3 describes the selection test focus and compares this with the focus of the outcome measure used along with whether the results found were significant. The reliability of the outcome measure was only reported by one author ${ }^{59}$.

\section{Selection tool used and Predictive Validity}

The selection tools reported fell into five broad but distinct categories: tests of (1) personal qualities, also known as non-academic attributes (e.g. Interviews); (2) cognitive ability, (3) academic attainment, or knowledge; (4) psychomotor skills and (5) combined ability tests. Almost all authors reported on multiple tests $28,30,33,35,55,56,58,59,61-63,67$.

Most found correlation between part ${ }^{5,28-31,54-56,60-62,64,65,67}$, if not all ${ }^{33}$, of the selection process employed and the outcome under study. However in most cases, the strength of relationship ( $r$ ), evaluated using Cohen's conventions ${ }^{68}$ ( 0.10 weak, 0.30 moderate, 0.5 strong), was a weak correlation between only part of the selection test or outcome measure $(n=9)^{5,29,30,55,56,59-61,67}$. In some cases correlations were reported between a section of an admission test $t^{5,29,30,61,64,65}$, such as a single interview question, and/or small sections of the outcome measure ${ }^{28,30,31,54,55}$, such as a single exam result. Three authors reported a negative correlation between the method of selection and their outcome measure ${ }^{28,31,58}$.

A moderate correlation between selection test and dental school assessment was found by four authors in relation to the UKCAT ${ }^{28}$, previous academic scores ${ }^{5}$, a non-structured interview ${ }^{55}$ and a manual dexterity test ${ }^{61}$. However most authors found weak or no significant correlation between similar tests and their own outcome measures ${ }^{5,28,34,35,55,58-64}$.

This article is protected by copyright. All rights reserved. 


\section{Personal qualities or non-academic attributes}

Nine studies investigated tests of non-academic attributes $28,29,34,55,58,59,62,64,65$, seven of these predicted outcomes ${ }^{28,29,55,59,62,64,65}$

The predictive validity of interviews was reported by seven authors $28,34,55,58,62,64,65$. Of these, four reported the use of unstructured interview formats ${ }^{55,62,64,65}$ (in one case with no interviewer training ${ }^{55}$ ). Two reported the use of a semi-structured (predetermined topics) interview ${ }^{34,58}$. One author reported a structured interview, employing a series of nine scenarios, of which each candidate was given three at random ${ }^{28}$. Three papers reported that interview performance did predict outcome on knowledge-based assessments ${ }^{55,64,65}$ whereas two other papers ${ }^{30,34}$ reported they did not. Whether an interview was structured or not had no relation to the outcome found.

Two of the above authors also investigated the use of another non-academic attribute test alongside the interview ${ }^{28,58}$. These are therefore added to the remaining two papers in this category ${ }^{29,59}$. Three authors investigated the use of a multiple-mini interview ${ }^{29,58,59}$, one author investigated the SJT component of the UKCAT (UK Clinical Aptitude Test) ${ }^{28}$. One author additionally reported on a personal statement ${ }^{59}$.

Of the three papers investigating the use of a multiple-mini interview ${ }^{29,58,59}$ Foley \& Hijazi found correlation with GPA on knowledge based assessments throughout dental school $\left(r=0.136^{59}, r=\right.$ $0.1^{29}$ ), whereas McAndrew ${ }^{58}$ found a negative correlation with assessment scores in year 1 . In relation to the use of an $\mathrm{SJT}^{28,32}$ the one author investigating this reported no correlation with exam results in first year of dental studies ${ }^{28}$ The use of a personal statement did not predict combined assessment scores throughout dental school ${ }^{59}$.

\section{Tests of cognitive ability}

Three studies explored the use of the cognitive ability component of UKCAT ${ }^{5,28,59}$ The UKCAT predicted grade point average throughout dental school $(r=0.077)^{59}$ in one study, but the remaining two studies found only partial correlation. Specifically, Lambe $^{28}$ found correlation with two of three knowledge based exams in first year $(r=0.32, r=0.38)$ while Lala ${ }^{5}$ found correlation between a subsection of the UKCAT and first year exam performance (DA $r=0.203$ ).

\section{Prior academic attainment \& knowledge based exams}

All studies applied prior academic attainment as an initial hurdle to application. Nine authors examined this s5,59,60,62 $^{\text {, and/or a different test of knowledge as a variable in their results }}{ }^{29,31,54,55,64}$. Four authors investigated high school grade point average $\mathrm{e}^{5,55,60,62}$, one author investigated first degree results- for graduate entry ${ }^{59}$, and one author investigated the influence of a prior medical degree ${ }^{54}$. One author introduced a multiple choice exam as part of their selection process, which was based on subjects taught at high school level ${ }^{31}$. A review of subject choice at either high school or previous degree level was carried out by three authors ${ }^{29,55,64}$.

Lala reported a moderate correlation between high school GPA and exam results in first year of dental school $\left.\right|^{5}$ (Semester $1 \mathrm{r}=0.437$, semester $2 \mathrm{r}=0.313$ ). Arnold ${ }^{55}$ found a weak but significant correlation between high school GPA and knowledge based assessments at year 1, half way and the end point of dental training. Lynch $^{60}$ reported a weak correlation between the Irish leaving

This article is protected by copyright. All rights reserved. 
certificate results and performance in Year 1 assessments, but found no correlation with final year assessments. The remaining two authors found no correlation between previous degree results in a graduate entry school ${ }^{59}$ or high school GPA ${ }^{62}$ and assessments throughout dental school.

In the four remaining studies in this category ${ }^{31,54,55,64}$, significant findings were reported by Beier ${ }^{54}$, Arnold $^{55}$ and Hoad-Reddick and Macfarlane ${ }^{64}$. Having a prior medical degree had a small but significant effect on results in year 1 of the dental course, but this influence was lost at the point of a licensure exam ${ }^{54}$. A review of high school subject choice showed weak but significant evidence of the positive effect of having studied school level Biology or Chemistry ${ }^{55,64}$. The introduction of a high school level multiple choice exam (HAM-Nat) as a predictor of study performance by Kothe ${ }^{31}$ showed differing linear relations in each cohort, and in some cases they even exhibited an inverse direction.

\section{Tests of psychomotor skills}

Two authors investigated the use of a manual dexterity test ${ }^{55,57}$. Arnold found weak correlation between the manual dexterity test and the practical component of the first dental examination taken at the midway point of dental studies $(r=0.20)^{55}$. Contrary to this, Giuliani reported that the use of a manual dexterity test at selection did not predict performance at a later date and that manual dexterity was something that could be taught ${ }^{57}$

\section{Combination Tests}

Seven papers reported on a selection process which included multiple tests ${ }^{30,33,35,56,61,63,67}$. These selection processes used a variety of personal qualities ${ }^{30,35,56,61,63}$, cognitive ability $^{30,33,56,61,67}$, knowledge $^{33,35,56,63,67}$ and psychomotor skills ${ }^{30,33,61}$ to arrive at a total admission score which was then compared with performance at a later date.

Christersson ${ }^{30}$ reported an 'Alternative admissions test' which consisted of tests of personal qualities, cognitive ability, academic attainment and psychomotor skills. Weak correlations were reported between small subsections of this test (Ravens advanced progressive matrices ${ }^{69}$, Folding, Empathy, Interview) with subsections of the outcome measure used; student self-assessment and examiner assessment of diagnostic skills and interpersonal skills graded on a Likert scale.

Buyse and Lievens ${ }^{67}$ reported the 'cognitive' portion of the Flemish admissions exam (FAE) which included 60 multiple choice questions (10 basic science [knowledge] and 50 cognitive ability). Weak correlations were reported between this and results in years 1-3 of dental studies (Year $1 r=0.17$, Year $2 \mathrm{r}=0.12$, Year $3 \mathrm{r}=0.10$ ) but it was not found to predict results in years 4 or 5 .

Buyse also reported the Flemish admissions exam (FAE) in a separate study ${ }^{56}$. In this study the subsections of the test were not investigated separately and instead the total result of the cognitive (including knowledge), silent reading and situational judgement test was compared with students GPA in years 1-3. A weak but significant correlation was found between students FAE score and GPA in years $1(r=0.21)$ and $2(r=0.14)$ of dental studies but not year 3 .

Beier $^{33}$ reported the Austrian Dental admissions test (ADAT), which includes cognitive and psychomotor components. This was show to predict students results in first year of dental studies $(r=0.462)$ and predict a student's ability to graduate on time $(p<0.05)$.

This article is protected by copyright. All rights reserved. 
Heintze reported the use of tests of general intelligence, spatial ability and manual dexterity (Cognitive and psychomotor). This included the use of Ravens advanced progressive matrices, tin models and folding, manual speed and accuracy and cavity reproduction. A moderate negative correlation was reported between two subsections of this test (Folding and Cavity reproduction) and course failure $(r=-0.32, r=-0.34)$ and a weak negative correlation was found between two other subsections (Matrices $r=-0.23$ and Tin models $r=-0.29$ ). Two sub sections (Folding $r=0.25$ and Tin models $r=0.27$ ) also showed a weak correlation with scores in a preclinical course in operative dentistry. The test of manual speed and accuracy did not produce significant results.

The remaining two studies published by Roding et al. ${ }^{35,63}$ compared a selection process which included GPA, written tests (personal statement, motivation statement and an essay on either general knowledge, society or science), and an interview. This test was then compared with failure and drop-out rates throughout year 1 and 2 in one study ${ }^{35}$ and 'professional competence', assessed by faculty on a Likert scale, in the other ${ }^{63}$. Neither produced significant findings.

\section{Research Design}

A retrospective study design was favoured by most authors $(n=13)^{5,28-31,33,54-56,58-60,67}$. Most compared performance on selection with performance at various points throughout dental school.

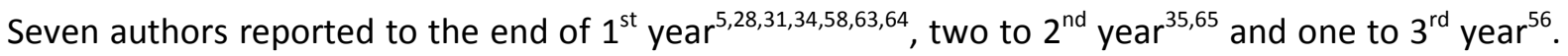
Of those reporting to final year $30,33,54,55,57,60-63,67$, only six authors followed the full cohort through to completion of studies ${ }^{30,54,55,60,61,67}$ and three of these reported crude measurements of 'ability to graduate on time ${ }^{\prime 33}$, 'drop-out rate ${ }^{61}$ and a Likert scale assessment of 'professional competence' ${ }^{63}$. Only two studies reported on the outcome of a licensure or 'final' examination ${ }^{54,55}$.

The majority of papers $(n=17)$ reported single site studies ${ }^{5,28-31,33-35,54,55,57,59-61,63-65}$ and six of these 17 papers were single-cohort studies ${ }^{28,34,58,64,65}$. The study population sizes ranged from $61^{34}$ to $796^{32}$ (median=122). No study reported a sample size calculation. There was duplication of study populations found across several of the papers by the same authors (i.e., the same study populations were reported twice ${ }^{29,33,35,54,56,59,63-65,67}$ ).

\section{Discussion}

One of the most significant findings of this research is the notable dearth of published research examining dental schools selection processes across Europe. There are 228 dental schools in Europe ${ }^{70}$ yet only fourteen have published any research in relation to admissions over the last 30 years. This is surprising, particularly when compared to a recent review of selection methods in medical education, which was carried out over a smaller time frame of 18 years and generated a much larger number of articles $(194)^{37}$. A vast array of data presumably exists in relation to dental schools admissions processes, and, no doubt, countless examples of good practice occur. However without sharing this information with wider audiences and publishing good quality research, we do not know if the admission processes used to gain entry to dental school are fit for purpose.

Although the current review was limited in relation to the points made above, some key findings did emerge which should inform future practice.

This article is protected by copyright. All rights reserved. 
(1) Tests of non-academic attributes

The importance of these skills in dentistry is highlighted by their inclusion in the set of competencies required for dentists practising in the European Union ${ }^{71}$. Typically this has been assessed by interview $^{30,34,35,58,61-65}$, a format known to have poor reliability and validity in student selection ${ }^{72-74}$. The evidence presented here confirms this by failing to reach any meaningful conclusion. There is some evidence that students admitted through interview are less likely to drop-out of dental school $^{30,33,35,61}$, but given the low drop-out rates in dentistry as a whole this argument has limited merit.

The onus is on dental schools to identify and adopt more robust methods for assessing nonacademic attributes. The evidence from medicine suggests that SJTs ${ }^{75-80}$ and MMIs ${ }^{36,81,82}$ are worth investigating. This evidence supports the use of MMIs and SJTs in predicting performance, particularly as students' progress into the clinical years ${ }^{29,59,67}$.

(2) Tests of cognitive ability

Only two countries reported the use of cognitive tests for dentistry in Europe, the UK ${ }^{5,34,59}$ and Sweden ${ }^{30,61}$ and consensus was not reached in relation to the predictive validity of the tools under investigation. Although the UKCAT is widely used by dental schools in the UK ${ }^{83}$, there is a paucity of research examining the predictive validity of this tool in dental education. Research in medical education has shown that the UKCAT is a predictor of outcomes at medical school ${ }^{84,85}$. Given the widespread use of this tool in the UKCAT, there is a pressing need to examine the predictive validity of the UKCAT and dental outcomes.

(3) Prior academic attainment \& knowledge based exams

Since the 1950s the validity of academic achievement in the selection of health care professionals has been questioned ${ }^{42,43,86,87}$. The evidence presented here shows high school GPA/prior attainment can predict performance in year $1^{5}$ but beyond this it has little ${ }^{55}$ or no correlation with future performance ${ }^{60,62}$. There is a lack of research in dentistry identifying how prior attainment relates to performance beyond graduation.

Prior attainment is no longer discriminating between candidates as increasing numbers of medical (dental) school applicants have top grades ${ }^{37,88}$. Moreover, an over-reliance on A-level results in the UK may create a distorted social intake to universities ${ }^{89}$. Further research is required to gauge the extent to which this is a problem in dental selection and education.

Further testing of knowledge at admission does not add any value to that already provided through prior attainment ${ }^{31}$.

(4) Tests of psychomotor skills

Whilst the practice of dentistry requires the ability to complete fine detail work, it appears from the literature that current tests of manual dexterity only have a weak correlation with early years psychomotor skills testing ${ }^{55}$ and that this skill can be taught ${ }^{57}$. This is consistent with other literature in the USA and Canada which have shown no practical utility of predictors of psychomotor performance ${ }^{90-92}$. As far back as the 1970s the practical component of the USA Dental Admissions

This article is protected by copyright. All rights reserved. 
Test was removed following research by Graham ${ }^{93}$ which showed perceptual ability tests to be more reliable. Current evidence therefore supports that tests of manual dexterity are not used as part of the dental selection process.

\section{(5) Combination tests}

The research published on differing combinations of tests fails to reach any meaningful conclusion. This is unsurprising given the multitude of different factors being assessed within each test ${ }^{30}$. The problem with this 'scatter-gun' approach is that it becomes unclear which part of the test predicted the outcome, even where authors attempted to differentiate this within their results ${ }^{30,61}$.

\section{Methodological Weaknesses in the current research}

\section{Study design}

One of the biggest weakness in the current literature are the weak study designs and the lack of long term follow up. Current research findings are limited to performance at dental school, and most to early years $5,28,31,34,35,58,64,65$. There is limited value of investigating year one performance in a five year course and what will become a potential 40 year career. Moreover, it appeared that new approaches to selection were adopted without piloting or testing, with no knowledge of whether or not they were fair, reliable or valid. Many studies were small scale and/or single site. We propose that collaboration across multiple dental schools to pilot and assess the utility of different, wellevidenced selection methods, would address some of the issues related to small sample sizes.

\section{Outcome Measures}

'A persistent problem with selection research relates to the issue of what outcomes we are trying to predict by using various selection methods', Patterson et al. ${ }^{37}$. This is true in the studies reported here. Most authors to date have focussed on the ability of selection methods to predict performance on a limited number of (mainly) knowledge based in-course assessments ${ }^{5,28,29,31,33-}$ $35,56,58-60,64,65,67$. This is often despite the selection method purporting to assess something other than the 'knowledge' of applicants $5,28,29,33,35,55,56,58,59,64,65,67$. The problem of selection tests (predictor variable) not aligning with the outcome criteria (criterion variable) has been discussed widely in the medical literature $e^{47,94}$.

Another issue raised by measuring against indicators of academic attainment rather than factors relating to the clinical practice of dentistry, is that we may simply be admitting those who perform well at academic assessments. Evidence from the wider medical literature suggests that academic attainment is a necessary but not sufficient requirement for becoming a competent clinician ${ }^{1,95-97}$.

\section{Theory driven research}

Within the published research there was a distinct lack of reference to the psychological theory supporting the use of the selection method being introduced. There is a wealth of research in the wider work psychology field in relation to selection methods including many systematic reviews, some of which span 85 years ${ }^{98-101}$. Despite this, dental schools are continuing to use methods with low predictive validity, such as personal statements, and ignoring those that are more valid. This problem is not unique to dentistry ${ }^{102}$ but does leave dental schools open to criticism and possible litigation from unsuccessful applicants. "Quick gains" should be achieved by drawing on the medical and wider literature, instead of attempting to 'reinvent the wheel'.

This article is protected by copyright. All rights reserved. 


\section{Distortion (artefacts)}

Small sample sizes and the single site nature of most studies may produce sampling error within the current research. Every study used academic qualifications as an initial hurdle to qualification, which diminishes the pool of candidates. Additionally the follow-up was only completed on those students who were successful in their application. The results published are therefore likely to underestimate the actual validity of the selection method. Future research should include corrections for range restrictions to highlight more accurate, and likely increased size, validity coefficients.

\section{Strengths and weaknesses of this study}

To the best of our knowledge, this is the first formal review of the literature on dental education selection criteria in Europe to have focused on the predictive validity of selection tools. The published literature across three databases was included in this review, and the process of reviewing was strengthened by numerous checks by all three authors. We omitted studies which were not published in English language and did not include conference abstracts, letters or unpublished literature. Our findings may therefore be subject to publication bias and the under-reporting of negative findings. A potential weakness of this study is that we did not systematically search the worldwide literature to explore the predictive validity of selection methods used. Although there is merit in learning from our international colleagues, we felt that the other confounding factors involved in selection would not be transferable to a European audience.

\section{Disclosure and Conflict of Interest}

CC, FP and JC had no conflict of interest and nothing to disclose.

\section{Conclusion}

It is clear from the discussion above that there is insufficient evidence of high quality from which to draw any conclusions as to the best selection methods or combinations of methods to use in dental school selection. Without this, designing selection frameworks for dentistry which are appropriately weighted, reliable and valid will remain a challenge. There is a need to move away from single site, small sample, and short-term designs to multi-centre ${ }^{26}$, longitudinal ${ }^{27}$, international studies. By gathering and analysing high-quality, longitudinal data, meaningful conclusions will be applicable to an international audience.

This article is protected by copyright. All rights reserved. 


\section{References}

1. Patterson, F., Ferguson, E. \& Thomas, S. Using job analysis to identify core and specific competencies: implications for selection and recruitment. Med. Educ. 42, 1195-1204 (2008).

2. NHS Eductation for Scotland. The dental workforce in Scotland 2016. (2016).

3. Higher Education Funding Council England. Non-Continuation Rates at English HEls-Trends for entrants 2005-06 to 2010-11. (2013).

4. Dental Schools Council. Guiding principles for the admission of dental students. 6-7 (2012). Available at: http://www.dentalschoolscouncil.ac.uk/wpcontent/uploads/2015/08/DSCAdmissionsPrinciplesFeb2012.pdf. (Accessed: 30th July 2017)

5. Lala, R., Wood, D. \& Baker, S. Validity of the UKCAT in applicant selection and predicting exam performance in UK dental students. J. Dent. Educ. 77, 1159-70 (2013).

6. Gallagher, J. \& Wilson, N. CU @ Dental SKL. (Stephen Hancocks, 2012).

7. King's College London. Dentistry. (2018). Available at: https://www.kcl.ac.uk/study/undergraduate/courses/dentistry-bds.aspx. (Accessed: 10th August 2018)

8. University of Leeds. Dental Surgery MChD/BChD. (2018). Available at: https://courses.leeds.ac.uk/201819/g033/dental-surgery-mchd-bchd-oral-science-bsc-mchdbchd-bsc. (Accessed: 10th August 2018)

9. University of Liverpool. Dental Surgery BDS. (2018). Available at: https://www.liverpool.ac.uk/study/undergraduate/courses/dental-surgery-bds/overview/. (Accessed: 10th August 2018)

10. University of Central Lancashire. Dentistry (Graduate Entry) BDS. (2018). Available at: https://www.uclan.ac.uk/courses/bds_dentistry_graduate_entry.php. (Accessed: 10th August 2018)

11. Manchester University. BDS Dentistry (first-year entry) (2019 entry). (2018). Available at: https://www.bmh.manchester.ac.uk/study/undergraduate/courses/2019/bds-dentistry-firstyear-entry/. (Accessed: 10th August 2018)

12. Newcastle University. a206 - Dental Surgery BDS. (2018). Available at: https://www.ncl.ac.uk/undergraduate/degrees/a206/\#entryrequirements. (Accessed: 10th August 2018)

13. University of Plymouth. BDS Dental Surgery. (2018). Available at: https://www.plymouth.ac.uk/courses/undergraduate/bds-dental-surgery. (Accessed: 10th August 2018)

14. The University of Sheffield. Entry Requirements - Bachelor of Dental Surgery. (2018). Available at: https://www.sheffield.ac.uk/dentalschool/undergraduate/bds/selection. (Accessed: 10th August 2018)

15. Yerevan State Medical University. Admission for foreign citizens. (2018). Available at: https://www.ysmu.am/en/page_list/admission/\#sthash.b78PpLvB.dpbs. (Accessed: 26th July 2018)

16. Inter HECS. Study Dentistry in Europe. (2017). Available at:

This article is protected by copyright. All rights reserved. 
https://www.interhecs.com/news/study-dentistry-in-europe/. (Accessed: 2nd July 2018)

17. The University of Aberdeen. Entrance Requirements | Institute of Dentistry. (2018). Available at: https://www.abdn.ac.uk/dental/study/bds/entrance-requirements.php. (Accessed: 2nd July 2018)

18. Barts and The London School of Medicine and Dentistry. Dentistry BDS 5 Years (A200). (2018). Available at: http://www.smd.qmul.ac.uk/undergraduate/courses/a200/. (Accessed: 3rd July 2018)

19. Dental Surgery (BDS HONS) A200. (2018). Available at:

http://www.qub.ac.uk/courses/undergraduate/dentistry-bds-a200/\#entry. (Accessed: 3rd July 2018)

20. University of Birmingham. BDS Dental Surgery - A200. (2018). Available at:

https://www.birmingham.ac.uk/undergraduate/courses/med/dental-surgery.aspx.

(Accessed: 10th August 2018)

21. University of Bristol. BDS Dentistry. (2018). Available at:

http://www.bristol.ac.uk/study/undergraduate/2019/dentistry/bds-dentistry/. (Accessed:

2nd July 2018)

22. Cardiff University. Dentistry. (2018). Available at:

https://www.cardiff.ac.uk/study/undergraduate/applying/admissions-criteria/dentistry.

(Accessed: 2nd July 2018)

23. University of Dundee. Dentistry BDS. (2018). Available at:

https://www.dundee.ac.uk/study/ug/dentistry/. (Accessed: 10th August 2018)

24. University of Glasgow. Dental School - Undergraduate. (2018). Available at:

https://www.gla.ac.uk/schools/dental/undergraduate/. (Accessed: 10th August 2018)

25. Rowland, K. C. \& Rieken, S. Rethinking Dental School Admission Criteria: Correlation Between Pre-Admission Variables and First-Year Performance for Six Classes at One Dental School. J.

Dent. Educ. 82, 411-416 (2018).

26. Smithers, S. et al. What Predicts Performance in Canadian Dental Schools ? J. Dent. Educ. 68, 598-613 (2004).

27. Gardner, S. P. \& Roberts-Thomson, K. F. Predicting high achievers in the University of Adelaide, Australia, Bachelor of Oral Health program, 2002-09. J. Dent. Educ. 76, 1646-56 (2012).

28. Lambe, P., Kay, E. \& Bristow, D. Exploring uses of the UK Clinical Aptitude Test-situational judgement test in a dental student selection process. Eur. J. Dent. Educ. 1-7 (2016). doi:10.1111/eje.12239

29. Foley, J. I. \& Hijazi, K. The admissions process in a graduate-entry dental school: can we predict academic performance? Br. Dent. J. 214, E4-E4 (2013).

30. Christersson, C., Bengmark, D., Bengtsson, H., Lindh, C. \& Rohlin, M. A predictive model for alternative admission to dental education. Eur. J. Dent. Educ. 19, 251-258 (2015).

31. Kothe, C., Hissbach, J. \& Hampe, W. The Hamburg selection procedure for dental students introduction of the HAM-Nat as subject-specific test for study aptitude. GMS Z. Med. Ausbild.

This article is protected by copyright. All rights reserved. 
30, Doc46 (2013).

32. Buyse, T. \& Lievens, F. Situational judgment tests as a new tool for dental student selection. J. Dent. Educ. 75, 743-749 (2011).

33. Beier, U. S., Kapferer, I., Ostermann, H., Staudinger, R. \& Dumfahrt, H. Impact of a novel dental school admission test on student performance at Innsbruck Medical University, Austria. J. Dent. Educ. 74, 531-538 (2010).

34. Kay, E., Bennett, J., Allison, P. \& Coombes, L. R. Evidence-informed dental student recruitment techniques. British Dental Journal 208, 127-131 (2010).

35. Röding, K. A new admission procedure to dental education at the karolinska institute an initial evaluation. Eur. J. Dent. Educ. 1, 114-122 (1997).

36. Cleland, J., Dowell, J., Mclachlan, J., Nicholson, S. \& Patterson, F. Identifying best practice in the selection of medical students (literature review and interview survey). (2012).

37. Patterson, F. et al. How effective are selection methods in medical education? A systematic review. Med. Educ. 50, 36-60 (2016).

38. Burton, N. W. \& Ramist, L. Predicting Success in College: SAT ${ }^{\circledR}$ Studies of Classes Graduating Since 1980. (2001).

39. Kuncel, N. R., Hezlett, S. A. \& Ones, D. S. A comprehensive meta-analysis of the predictive validity of the Graduate Record Examinations: Implications for graduate student selection and performance. Psychol. Bull. 127, 162-181 (2001).

40. Trapmann, S., Hell, B., Hirn, J.-O. W. \& Schuler, H. Meta-Analysis of the Relationship Between the Big Five and Academic Success at University. J. Psychol. 215, 132-151 (2007).

41. Schuler, H., Funke, U. \& Baron-Boldt, J. Predictive Validity of School Grades -A Meta-analysis. Appl. Psychol. 39, 89-103 (1990).

42. Moore B. C. R. and Peel E. A. Predicting aptitude for dentistry. Occup. Psychol. 25, 192 (1951).

43. Smith, B. G. N. The prediction of performance amongst dental personnel in training. (University of London, 1974).

44. McAndrew, R. \& Greatrix, R. The UKCAT test: developments, research and its use by dental schools in the UK. Br. Dent. J. 216, 191-194 (2014).

45. Patterson, F. \& Ferguson, E. Selection for medical education and training. in Understanding Medical Education: Evidence, Theory and Practice (ed. Swanwick, T.) (Wiley Blackwell, 2010).

46. Kelley, T. L. Interpretation of Educational Measurements. (Macmillan, 1927).

47. Arnold, J. \& Randall, R. Work Psychology: Understanding Human Behaviour in the workplace. (FT Publishing International, 2016).

48. PRISMA-P (Preferred Reporting Items for Systematic review and Meta-Analysis Protocols) 2015 checklist: recommended items to address in a systematic review protocol*.

49. Walker, E., Hernandez, A. V \& Kattan, M. W. Meta-analysis: Its strengths and limitations. Cleve. Clin. J. Med. 75, (2008).

This article is protected by copyright. All rights reserved. 
50. Cochrane Collaboration. Cochrane Effective Practice and Organisation of Care (EPOC). Synthesising results when it does not make sense to do a meta-analysis. EPOC Resources for review authors. (2017).

51. Haidich, A. B. Meta-analysis in medical research. Hippokratia 14, 29-37 (2010).

52. Borenstein, M., Hedges, L. V, Higgins, J. P. T. \& Rothstein, H. R. When Does it Make Sense to Perform a Meta-Analysis? in Introduction to Meta-Analysis. ( John Wiley \& Sons, Ltd, 2009).

53. Popay, J. et al. Guidance on the Conduct of Narrative Synthesis in Systematic Reviews. A Prod. from ESRC Methods Program. 211-219 (2006). doi:10.1111/j.1523-536x.1995tb00261.x

54. Beier, U. S., Kapferer, I., Burtscher, D., Ulmer, H. \& Dumfahrt, H. Impact of a prior medical degree on students' dental school performance in Innsbruck, Austria. J. Dent. Educ. 76, 341-7 (2012).

55. Arnold, W. H., Gonzalez, P. \& Gaengler, P. The predictive value of criteria for student admission to dentistry. Eur. J. Dent. Educ. 15, 236-243 (2011).

56. Buyse, T., Lievens, F. \& Martens, L. Admission systems to dental school in Europe: A closer look at Flanders. Eur. J. Dent. Educ. 14, 215-220 (2010).

57. Giuliani, M. et al. Is manual dexterity essential in the selection of dental students? Br. Dent. J. 203, 149-155 (2007).

58. McAndrew, R., Ellis, J. \& Valentine, R. A. Does a selection interview predict year 1 performance in dental school? Eur. J. Dent. Educ. 21, 108-112 (2017).

59. Foley, J. I. \& Hijazi, K. Predictive value of the admissions process and the UK Clinical Aptitude Test in a graduate-entry dental school. Br. Dent. J. 218, 687-689 (2015).

60. Lynch, C. D., McConnell, R. J. \& Hannigan, A. Dental school admissions in Ireland: Can current selection criteria predict success? Eur. J. Dent. Educ. 10, 73-79 (2006).

61. Heintze, U., Radeborg, K., Bengtsson, H. \& Stenlaas, A. Assessment and evaluation of individual prerequisites for dental education. Eur. J. Dent. Educ. 8, 152-160 (2004).

62. Fenlon, M. R., McCartan, B. E., Sheriff, M. \& Newton, T. J. Personality of dental students in two dental schools in the United Kingdom and in Ireland. Eur. J. Dent. Educ. 5, 173-176 (2001).

63. Röding, K. Professional competence in final-year dental undergraduates: assessment of students admitted by individualised selection and through traditional modes. Eur. J. Dent. Educ. 5, 12-6 (2001).

64. Hoad-Reddick, G. \& Macfarlane, T. V. An analysis of an admissions system: can performance in the first year of the dental course be predicted? Br. Dent. J. 186, 138-42 (1999).

65. Hoad-Reddick, G. \& Macfarlane, T. V. Organising the introduction of, and evaluating interviewing in, an admissions system. Eur. J. Dent. Educ. 3, 172-179 (1999).

66. Van Der Vleuten, C. P. M. The Assessment of Professional Competence: Developments, Research and Practical Implications. Adv. Heal. Sci. Educ. 1, 41-67 (1996).

67. Buyse, T. \& Lievens, F. Situational Judgment Tests as a New Tool for Dental Student Selection. J. Dent. Educ. 743, (2011).

This article is protected by copyright. All rights reserved. 
68. Cohen, J. Statistical Power Analysis for the Behavioral Sciences. (Taylor and Francis, 2013).

69. Raven, J., Raven, J. \& Court, J. The advanced progressive matrices. in Manual for Raven's progressive matrices and vocabulary scales (TX: Harcourt Assessment, 1998).

70. European Orthodontic Society. Dental Schools in Europe. (2018). Available at: https://www.eoseurope.org/useful_links/dental_schools. (Accessed: 6th July 2018)

71. Council of European dentists. EU Manual of Dental Practice. (2015).

72. Goho, J. \& Blackman, A. The effectiveness of academic admission interviews: An exploratory meta-analysis. Med. Teach. 28, 335-340 (2006).

73. Harasym, P. H., Woloschuk, W., Mandin, H. \& Brundin-mather, R. Reliability and validity of interviewers'. Acad. Med. 71, S40-2 (1996).

74. Kreiter, C. D., Yin, P., Solow, C. \& Brennan, R. L. Investigating the Reliability of the Medical School Admissions Interview. Adv. Heal. Sci. Educ. 9, 147-159 (2004).

75. Patterson, F., Zibarras, L. \& Ashworth, V. Situational judgement tests in medical education and training: Research, theory and practice: AMEE Guide No. 100. Med. Teach. 38, 3-17 (2016).

76. Chan, D. \& Schmitt, N. Situational Judgment and Job Performance. Hum. Perform. 15, 233254 (2002).

77. Cousans, F. et al. Evaluating the complementary roles of an SJT and academic assessment for entry into clinical practice. Adv. Heal. Sci. Educ. 22, 401-413 (2017).

78. Lievens, F., Buyse, T. \& Sackett, P. R. The Operational Validity of a Video-Based Situational Judgment Test for Medical College Admissions: Illustrating the Importance of Matching Predictor and Criterion Construct Domains. J. Appl. Psychol. 90, 442-452 (2005).

79. Lievens, F. \& Sackett, P. R. The validity of interpersonal skills assessment via situational judgment tests for predicting academic success and job performance. J. Appl. Psychol. 97, 460-468 (2012).

80. McDaniel, M. A., Psotka, J., Legree, P. J., Yost, A. P. \& Weekley, J. A. Toward an understanding of situational judgment item validity and group differences. J. Appl. Psychol. 96, 327-36 (2011).

81. Husbands, A. \& Dowell, J. Predictive validity of the Dundee multiple mini-interview. Med. Educ. 47, 717-725 (2013).

82. Eva, K. W. et al. Association Between a Medical School Admission Process Using the Multiple Mini-interview and National Licensing Examination Scores. JAMA 308, 2233 (2012).

83. McAndrew, R. \& Salem-Rahemi, M. Advice and guidance on the admissions process to UK dental schools. Dent. Update 40, 129-32, 135-8, 141-2 (2013).

84. Sartania, N., McClure, J. D., Sweeting, H. \& Browitt, A. Predictive power of UKCAT and other pre-admission measures for performance in a medical school in Glasgow: a cohort study. BMC Med. Educ. 14, 116 (2014).

85. MacKenzie, R. K., Cleland, J. A., Ayansina, D. \& Nicholson, S. Does the UKCAT predict performance on exit from medical school? A national cohort study. BMJ Open 6, e011313

This article is protected by copyright. All rights reserved. 
(2016).

86. Glyn Jones, J. C. Dental student selection-the prediction of success. J. Dent. 7, 329-338 (1979).

87. McManus I, Powis D, Wakeford R, Ferguson E, James D, R. P. Intellectual aptitude tests and A levels for selecting UK school leaver entrants for medical school. Br. Med. J. 331, 555-559 (2005).

88. McManus, C., Woolf, K. \& Dacre, J. E. Even one star at A level could be 'too little, too late' for medical student selection. BMC Med. Educ. 8, 16 (2008).

89. Milburn, A. Unleashing Aspiration: The Final Report of the Panel on Fair Access to the Professions. (2009).

90. de Andrés, A. G., Sánchez, E., Hidalgo, J. J. \& Díaz, M. J. Appraisal of psychomotor skills of dental students at University Complutense of Madrid. Eur. J. Dent. Educ. 8, 24-30 (2004).

91. Gansky, S. a et al. Reliability and validity of a manual dexterity test to predict preclinical grades. J. Dent. Educ. 68, 985-94 (2004).

92. Oudshoorn, W. The Utility of Canadian DAT Perceptual Ability and Carving Dexterity scores as predictors of psychomotor performance in first-year operative dentistry. J. Dent. Educ. 67, (2003).

93. Graham, J. W. Substitution of perceptual-motor ability test for chalk carving in Dental Admission Testing Program. J. Dent. Educ. 36, 9-14 (1972).

94. Alliger, G. M., Tannenbaum, S. I., Bennett, W., Traver, H. \& Shotland, A. A Meta-analysis of the Relations Among Training Criteria. Pers. Psychol. 50, 341-358 (1997).

95. Greengross, S. What patients want from doctors. in Choosing Tomnorrow's Doctors (eds. Allen, I., Brown, P. \& Hughes, P.) 12-19 (Policy Studies Institute, 1997).

96. Hughes, P. Can we improve on how we select medical students. J. R. Soc. Med. 95, 18-22 (2002).

97. Reede, J. Predictors of success in medicine. Clin. Orthop. Relat. Res. 362, 72-7 (1999).

98. Schmidt, F. L. \& Hunter, J. E. The Validity and Utility of Selection Methods in Personnel Psychology: Practical and Theoretical Implications of 85 Years of Research Findings. Psychol. Bull. 124, 262-274 (1998).

99. Robertson, I. \& Smith, M. Personnel Selection. J. Occup. Organ. Psychol. 74, 441-72 (2001).

100. Hough, L. M. \& Oswald, F. L. Personnel Selection: Looking Toward the Future-Remembering the Past. Annu. Rev. Psychol 51, 631-664 (2000).

101. Sackett, P. \& Lievens, F. Personnel Selection. Annu. Rev. Psychol 16.1-16.32 (2008).

102. Strategic Human Resource Management. (Blackwell, 2007).

This article is protected by copyright. All rights reserved. 
Table 1

Types of Validity, summary of Chapter 4 in Arnold \& Randall 2016 ${ }^{47}$

\begin{tabular}{|c|c|c|c|c|}
\hline Type & What it is & Variations & Advantages & Disadvantages \\
\hline \multirow[t]{3}{*}{$\begin{array}{l}\text { Criterion } \\
\text { Related } \\
\text { Validity }\end{array}$} & \multirow[t]{3}{*}{$\begin{array}{l}\text { The strength of } \\
\text { relationship between the } \\
\text { predictor and the criterion } \\
\text { This gives a validity } \\
\text { coefficient }\end{array}$} & $\begin{array}{l}\text { Predictive } \\
\text { (follow-up) } \\
\text { Collects predictor } \\
\text { information then } \\
\text { follows up } \\
\text { candidates to } \\
\text { collect criterion } \\
\text { data }\end{array}$ & $\begin{array}{l}\text { Follows candidates } \\
\text { through from } \\
\text { selection to in job } \\
\text { performance }\end{array}$ & $\begin{array}{l}\text { Length of time to complete } \\
\text { Only successful candidates } \\
\text { will be tested at outcome }\end{array}$ \\
\hline & & $\begin{array}{l}\text { Concurrent } \\
\text { (Criteria related) } \\
\text { Predictor data are } \\
\text { obtained from } \\
\text { existing } \\
\text { employees on } \\
\text { whom criterion } \\
\text { data are already } \\
\text { available }\end{array}$ & $\begin{array}{l}\text { The organisation is } \\
\text { not required to collect } \\
\text { predictor data from } \\
\text { job applicants and the } \\
\text { ignore this during } \\
\text { selection } \\
\text { No time delay } \\
\text { between collection of } \\
\text { predictor and criterion } \\
\text { data } \\
\text { No lengthy follow-up }\end{array}$ & $\begin{array}{l}\text { Incomplete sample and } \\
\text { probably biased } \\
\text { Workers may provide a } \\
\text { population that may be } \\
\text { different to the population } \\
\text { of applicants } \\
\text { Current job holders have } \\
\text { already been selected using } \\
\text { existing company selection } \\
\text { procedures and represent a } \\
\text { pre-selected group of } \\
\text { people who have been with } \\
\text { the organisation for some } \\
\text { time } \\
\text { May test skills acquired } \\
\text { whilst doing the job }\end{array}$ \\
\hline & & $\begin{array}{l}\text { Incremental } \\
\text { Validity } \\
\text { How much does } \\
\text { adding an } \\
\text { additional tool } \\
\text { increase the } \\
\text { predictive power }\end{array}$ & $\begin{array}{l}\text { Allows a cost/benefit } \\
\text { analysis of using } \\
\text { additional tools }\end{array}$ & $\begin{array}{l}\text { Difficult to interpret } \\
\text { analysis }\end{array}$ \\
\hline Faith & $\begin{array}{l}\text { Belief that a selection } \\
\text { method is valid }\end{array}$ & & User acceptability & Not based on evidence \\
\hline Face & It 'looks' right & & $\begin{array}{l}\text { Candidate } \\
\text { acceptability }\end{array}$ & Not based on evidence \\
\hline Content & $\begin{array}{l}\text { Established on a logical } \\
\text { basis } \\
\text { A predictor shows content } \\
\text { validity when it covers a } \\
\text { representative sample of } \\
\text { the behaviour domain } \\
\text { being measured }\end{array}$ & & $\begin{array}{l}\text { Logical approach } \\
\text { Content appropriate } \\
\text { to target role }\end{array}$ & No statistical basis \\
\hline Construct & $\begin{array}{l}\text { Identifies the psychological } \\
\text { characteristics (or } \\
\text { constructs) such as } \\
\text { intelligence, emotional } \\
\text { stability or manual } \\
\text { dexterity that underlie } \\
\text { successful performance of } \\
\text { the task in question }\end{array}$ & & $\begin{array}{l}\text { Important facet of } \\
\text { understanding what } \\
\text { the instrument } \\
\text { actually measures }\end{array}$ & $\begin{array}{l}\text { Assessed by indirect means } \\
\text { and usually validated by } \\
\text { comparing with results of } \\
\text { an already established } \\
\text { measure }\end{array}$ \\
\hline
\end{tabular}

This article is protected by copyright. All rights reserved. 


\begin{tabular}{|c|c|c|c|c|c|c|c|c|}
\hline Author/Year & Study Population * & Follow Up & Predictor & & Outcome Measure & & $\begin{array}{c}\text { Significan } \\
t \\
\text { Yeso/ } / P \\
\text { artial } \\
\end{array}$ & 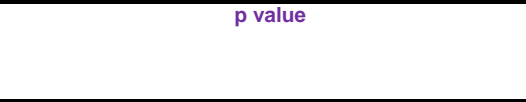 \\
\hline \multirow{2}{*}{$\begin{array}{l}\text { McAndrew et al } \\
2017\end{array}$} & $n=117$ & \multirow[t]{2}{*}{$\overline{B D S 1}$} & Semi structured Interview (Newcastle) & - & BDS 1 Assessments (4 exams) & $\bar{\square}$ & $\mathrm{N}$ & \\
\hline & $\begin{array}{l}\text { Two single cohorts } \\
\text { (Parallel study) }\end{array}$ & & MMI (Card & - & BDS1 Assessments (2 exams) & $\square$ & $\mathrm{N}$ & \\
\hline \multirow{2}{*}{$\begin{array}{l}\text { Lambe et al } \\
2016\end{array}$} & \multirow{2}{*}{$\begin{array}{l}\mathrm{n}=228 \\
\text { Single Cohort }\end{array}$} & \multirow[t]{2}{*}{ BDS1 } & Interview & 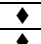 & $\begin{array}{l}\text { BDS } 1 \text { Assessments (3 exams) } \\
\text { BDS 1 Assessments ( } 3 \text { exams) }\end{array}$ & $\frac{1}{\square}$ & $\frac{N}{N}$ & \\
\hline & & & UKCAT \& SJT & 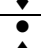 & BDS 1 Assesssments (3 exams) & 口 & Partial & $\operatorname{Exam} 1 p=<0.01 \operatorname{Exam} 2 p=<0.05 \operatorname{Exam} 3=\mathrm{N}$ \\
\hline \multirow{4}{*}{$\begin{array}{l}\text { Foley \& Hijazi } \\
2015\end{array}$} & \multirow{4}{*}{$\begin{array}{l}n=71 \\
\text { Four cohorts } \\
\text { (Only one cohort to final } \\
\text { year) }\end{array}$} & \multirow[t]{4}{*}{ Final Year } & Preadmission academic score (PAS) & $\square$ & \multirow{4}{*}{ Combined assessment scores year 1-4 } & \multirow{4}{*}{ ㅁ } & $\mathrm{N}$ & \\
\hline & & & $\frac{\text { UCAS }}{\text { MMI }}$ & $\div$ & & & $\frac{\mathrm{N}}{\mathrm{Y}}$ & $p=0.001$ \\
\hline & & & UKCAT & $\bullet$ & & & $\mathrm{Y}$ & $p=0.019$ \\
\hline & & & UKCAT percentile & $\bullet$ & & & $\begin{array}{l} \\
Y\end{array}$ & $p=0.001$ \\
\hline \multirow[t]{6}{*}{$\begin{array}{l}\text { Christersson et al } \\
2015\end{array}$} & \multirow[t]{6}{*}{$\begin{array}{l}n=283 \\
\text { Six Cohorts }\end{array}$} & \multirow[t]{6}{*}{ Final Year } & \multirow{6}{*}{$\begin{array}{l}\text { Alternative admission group } \\
\text { - Problem solving matrices } \\
\text {-Spatial capcity test (folding \& tin models) } \\
\text { - Manual Dexterity } \\
\text { - Empathy } \\
\text { - Interview }\end{array}$} & \multirow{6}{*}{$\begin{array}{l}\dot{\bullet} \\
\dot{\square} \\
\mathscr{H}\end{array}$} & Drop-out rate & $\square$ & Partial & $\begin{array}{l}\text { Comparison with Grade Admission } p=<0.001 \text { Tin } \\
\text { Models } p=<0.05\end{array}$ \\
\hline & & & & & Study rate & $\square$ & Partial & $\begin{array}{l}\text { Comparison with Grade Admission } p=<0.001 \text { Empathy } \\
p=<0.05\end{array}$ \\
\hline & & & & & Examinations failed & $\square$ & Partial & Matrices $p=<0.01$ \\
\hline & & & & & $\begin{array}{l}\text { Clinical Examination } \\
\text { (Examiners= E) (Students Self Assessment= S) }\end{array}$ & + & Partial & $\begin{array}{l}\text { Matrices } p=<000.1 \text { Folding } S=0.19 p=<0.05 \\
\text { Empathy } S=0.07 p=<0.001\end{array}$ \\
\hline & & & & & $\begin{array}{l}\text { Diagnostic skills } \\
(\text { Examiners= }=E) \text { (Students Self Assessment= S) }\end{array}$ & - & Partial & Matrices $S p=<0.01$ Empathy $E p=<0.05$ \\
\hline & & & & & Interpersonal skills & 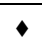 & Partial & $\begin{array}{l}Y \text { Matrices } S p=<0.05 \quad Y \text { Empathy } E p=<0.01 Y \\
\text { Interview } S p=<0.001\end{array}$ \\
\hline \multirow{7}{*}{$\begin{array}{l}\text { Kothe et al } \\
2013\end{array}$} & \multirow{7}{*}{$\begin{array}{l}n=91 \\
\text { Two cohorts }\end{array}$} & \multirow[t]{7}{*}{ BDS 2} & HAM-Nat Natural Sciences Test & & $\begin{array}{l}\text { Physics Exam } \\
\text { Chemistry Exam }\end{array}$ & $\frac{1}{\square}$ & $\frac{N}{N}$ & \\
\hline & & & & & Science Exam - Physics & ㅁ & Partial & Cohort 1 only $p=<0.05$ \\
\hline & & & & & Science Exam - Chemistry & $\bar{\square}$ & $\mathrm{N}$ & 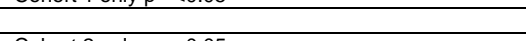 \\
\hline & & & & $\square$ & Science Exam-Biology & 믐 & Partial & Cohort 2 only $p=<0.05$ \\
\hline & & & & & Dental Exam-Anatomy & 口 & $\mathrm{N}$ & \\
\hline & & & & & Dental Exam- Physiology & 믐 & $\mathrm{N}$ & \\
\hline & & & & & $\begin{array}{l}\text { Dental Exam- Biochemistry } \\
\text { Dental Exam- Dental Prosthetics }\end{array}$ & 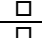 & $\frac{N}{N}$ & \\
\hline $\begin{array}{l}\text { Lala et al } \\
2013\end{array}$ & $\begin{array}{l}n=135 \\
2 \text { Cohorts }\end{array}$ & BDS 1 & $\begin{array}{l}\text { UKCAT } \\
\text { Including Subtest scores } \\
\text { QR/DA/ VR/ AR }\end{array}$ & $\bullet$ & Semester 1 = Human Body & $\square$ & Partial & DA only $p=<0.05$ \\
\hline & & & & & Semester $2=$ Oral Cavity & $\square$ & Partial & DA only $p=<0.05$ \\
\hline $\begin{array}{l}\text { Foley \& Hijazi } \\
2013\end{array}$ & $\begin{array}{l}n=75 \\
\text { Four Cohorts }\end{array}$ & Final Year & Previous academic subject & $\square$ & & & $\mathrm{N}$ & Descriptive statistics only \\
\hline & year) & & MMI & - & Combined assessment scores year 1-4 & 口 & Partial & $\begin{array}{l}\text { Teamwork } p=0.024 \\
\text { Communication skills } p=0.035 \\
\text { Work Experiencet } p=0.001 \\
\text { Manual Dexterity } p=0.003\end{array}$ \\
\hline $\begin{array}{l}\text { Beier et al } \\
2012\end{array}$ & $\begin{array}{l}\mathrm{n}=122 \\
\text { Six Cohorts }\end{array}$ & Final Year & $\begin{array}{l}\text { Prior Medical Degree } \\
\text { (PMD) }\end{array}$ & & Austrian DAT & $\begin{array}{l}\square \\
\bullet \\
\mathscr{H}\end{array}$ & $\mathrm{Y}$ & $p=0.042^{*}$ \\
\hline & & & & $\square$ & Clinical performance after 1 st year & 口 & $\mathrm{Y}$ & $p=0.03^{*}$ \\
\hline & & & & & Outcome of Licensure examination & $\square$ & Partial & $\begin{array}{l}\text { Prosthodontics } p=0.013 \\
\text { Oral \& Maxillofacial Surgery } p=p=0.005\end{array}$ \\
\hline $\begin{array}{l}\text { Arnold et al } \\
2011\end{array}$ & $n=196$ & Final Year & High school GPA & $\square$ & & & $\mathrm{Y}$ & ALL $p<0.001$ \\
\hline & & & High School Subject choice & 口 & $\begin{array}{l}\text { Natural Dental Science Examination (NDS) (end } \\
\text { of 1st year) }\end{array}$ & 口 & Partial & Biology component of NDS only $\mathrm{p}=0.008$ \\
\hline & & & Non-structured interview & - & $\begin{array}{l}\text { First Dental Examination (DE) (After } 2.5 \text { years) } \\
\text { State Board Examination (SBE)(Afer } 5 \text { years) }\end{array}$ & $\mathscr{H}$ & Y & $\begin{array}{l}\text { NDS } p<0.001 \\
\text { DE } p<0.026 \\
\text { SBE } p<0.006\end{array}$ \\
\hline & & & Practical Test & $\mathscr{H}$ & & & Partial & Practical component of first dental exam $p<0.05$ \\
\hline $\begin{array}{l}\text { Buyse and Lievens } \\
2011\end{array}$ & $n=796$ & Final Year & $\begin{array}{l}\text { Cognitive exam } \\
\text { (MCQ } 10 \text { questions basic science + cognitive } \\
\text { test } 50 \text { MCQs) }\end{array}$ & $\bullet$ & & & Partial & $\begin{array}{l}\text { Year } 1 p<0.01 \\
\text { Year } 2 p<0.01 \\
\text { Year } 3 p<0.05\end{array}$ \\
\hline & & & $\begin{array}{l}\text { Silent reading test } \\
\text { (Read Medical literature then answer MCQ) }\end{array}$ & $\bullet$ & GPA in the five years of dental studies & ㄴ & $\mathrm{N}$ & \\
\hline & & & $\begin{array}{l}\text { SJT } \\
\text { SJ }\end{array}$ & 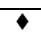 & & & Partial & Year $5 \mathrm{p}<0.01$ \\
\hline $\begin{array}{l}\text { Buyse et al } \\
2010\end{array}$ & $\mathrm{n}=547$ & & $\begin{array}{l}\text { Flemish Admission Exam } \\
\text {-Cognitive exam } \\
\text {-Silent reading test } \\
\text {-SJT }\end{array}$ & 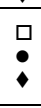 & Students GPA for first 3 years of dental education & $\square$ & Partial & $\begin{array}{l}\text { Year } 1 \mathrm{p}<0.05 \\
\text { Year } 2 \mathrm{p}<0.05\end{array}$ \\
\hline $\begin{array}{l}\text { Beier et al } \\
2010\end{array}$ & $n=97$ & $\begin{array}{l}\text { Partial to } \\
\text { final year }\end{array}$ & $\begin{array}{l}\text { Austrian DAT } \\
\text { Theoretical \& Practical Components }\end{array}$ & $\stackrel{\dot{\square}}{\mathscr{H}}$ & Perfomance in BDS 1 & $\square$ & $\mathrm{Y}$ & $p<0.01$ \\
\hline $\begin{array}{l}\text { Kay et al } \\
2010\end{array}$ & $n=62$ & BDS 1 & Interview & - & $\begin{array}{l}\text { Graduation on time } \\
\text { GAMSAT } \\
\text { Student progress at the end of } 1 \text { st year }\end{array}$ & $\dot{\square}$ & $\begin{array}{l}\mathrm{Y} \\
\mathrm{N}\end{array}$ & $p<0.05$ \\
\hline $\begin{array}{l}\text { Giuliani et al } \\
2007\end{array}$ & $n=433$ & Year5 & Basic Manual Dexterity Tests (BMD) & H & $\begin{array}{l}\text { Admission to Dental School } \\
\text { Repeat of same tests at } 3 \& 5 \text { Years }\end{array}$ & $\mathscr{H}$ & $\mathrm{N}$ & \\
\hline $\begin{array}{l}\text { Lynch et al } \\
2006\end{array}$ & $n=95$ & Final Year & Leaving Certificate Examination Ireland & 口 & $\begin{array}{l}\text { First Dental Exam } \\
\text {-Anatomy, Biochemistry, Physiology }\end{array}$ & 口 & $\mathrm{Y}$ & $p<0.05$ \\
\hline & & & & & $\begin{array}{l}\text { Final Dental Exam } \\
\text { - Restorative Dentistry, Dental Surgery, Oral } \\
\text { Health and Development }\end{array}$ & 口 & $\mathrm{N}$ & \\
\hline $\begin{array}{l}\text { Heintze et al } \\
2004\end{array}$ & $n=51-191$ & Final Year & $\begin{array}{l}\text { Tests of general intelligence, spatial ability } \\
\text { and manual dexterity }\end{array}$ & $\dot{2}$ & $\begin{array}{l}\text { Number of courses failed (CF) } \\
\text { Pre-clinical course in Operative Dentistry (POD) }\end{array}$ & 口 & Partial & $\begin{array}{l}\text { CF Matrices } p<0.01 \text {, Folding } p<0.001 \text {, Cavity } \\
\text { Reproduction } p<0.01 \text {, } \\
\text { POD Folding } p<0.01 \text {, Tin Models } p<0.01\end{array}$ \\
\hline & & & Empathy and Social Competence & + & & 口 & $\mathrm{N}$ & \\
\hline & & & Interviews & - & $\begin{array}{l}\text { Temporary break off of studies or repeating a } \\
\text { term \& drop-outs } \\
\text { Social competence and empathy }\end{array}$ & 口 & Partial & CF $p<0.05$ \\
\hline $\begin{array}{l}\text { Fenlon et al } \\
2001\end{array}$ & $\begin{array}{l}\mathrm{n}=302 \\
\text { Dental students in 3, } 4 \text { \& }\end{array}$ & $\begin{array}{l}\text { Partial to } \\
\text { final year }\end{array}$ & Interview (UMDS- GST) & - & $\begin{array}{l}\text { The Adult Eysenck Personality Questionnaire } \\
\text { Revised } \\
\text { short-form (EPQ-R) }\end{array}$ & & Partial & $\begin{array}{l}\text { Male age 16-20 Psychoticism } p<0.05 \\
\text { Female and Male age } 21-30 \text { Extraversion } p<0.05 \\
\text { Female age 21-30 Neuroticism } p<0.05\end{array}$ \\
\hline & 5 th year & & School exam results (TDS- Dublin) & 口 & & - & $\mathrm{N}$ & \\
\hline $\begin{array}{l}\text { Röding } \\
2001\end{array}$ & $n=128$ & Final Year & $\begin{array}{l}\text { Individualised Selection Process } \\
\text { (Written Tests, GPA and Interview) }\end{array}$ & $\stackrel{\square}{\bullet}$ & $\begin{array}{l}\text { Professional Competence as assessed by faculty } \\
\text { on a } 1-7 \text { scale }\end{array}$ & $\bullet$ & $\mathrm{N}$ & Descriptive statistics only \\
\hline $\begin{array}{l}\text { Hoad-Reddick \& } \\
\text { Macfarlane }\end{array}$ & $n=112$ & Year 1 & Interview & - & Performance during year 1 of the dental course & & Partial & $\begin{array}{l}\text { High score for leadership less likely to fail semester } 2 \\
p<0.03\end{array}$ \\
\hline & & & Subject Choice at A level & $\square$ & & $\square$ & Partial & $\begin{array}{l}\text { Without Biology A level- more likely to fail semester } 1 \\
\text { of } 2 \mathrm{p}<0.01 \\
\text { Without Chemistry A level- Imore likely to fail semester } \\
2 \mathrm{p}<0.02\end{array}$ \\
\hline $\begin{array}{l}\text { Hoad-Reddick \& } \\
\text { Macfarlane } \\
\text { 1999a }\end{array}$ & $n=117$ & Year 2 & Interview & - & Performance in Year 1 \& 2 of dental school & 口 & Partial & $\begin{array}{l}\text { Interview- } \text { - high leadership score less likely to fail } \\
\text { semester } 2 p=0.03\end{array}$ \\
\hline $\begin{array}{l}\text { Röding } \\
1997\end{array}$ & $n=169$ & Year 2 & $\begin{array}{l}\text { Grade admission } \\
3 \text { Written Assignments }\end{array}$ & 口 & Drop-outs & $\square$ & $\mathrm{N}$ & Descriptive statistics only \\
\hline & & & & 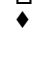 & 4 Exam results throughout Year $1 \& 2$ & 口 & & \\
\hline
\end{tabular}




\begin{tabular}{|l|l|}
\hline \multicolumn{2}{|c|}{ KEY } \\
\hline $\begin{array}{l}\text { Personal qualities/ } \\
\text { non-academic attributes }\end{array}$ & \\
\hline Cognitive abiity & \\
\hline $\begin{array}{l}\text { Academic attainment/ } \\
\text { knowledge }\end{array}$ & $\square$ \\
\hline Psychomotor skills & $\mathscr{H}$ \\
\hline
\end{tabular}

This article is protected by copyright. All rights reserved. 
Table 3- Predictor versus outcome measure focus

\begin{tabular}{|c|c|c|c|}
\hline Author/ Year & Predictor & Outcome Measure & $\begin{array}{c}\text { Significant } \\
\text { Yes/No/ } \\
\text { Partial (Part of the } \\
\text { predictor and/or } \\
\text { part of the } \\
\text { outcome) } \\
\end{array}$ \\
\hline McAndrew et al 2017 & $\nabla$ & $\square$ & $\mathrm{N}$ \\
\hline Lambe et al 2016 & $\bullet \bullet$ & $\square$ & Partial \\
\hline Foley \& Hijazi 2015 & $\square \diamond \bullet$ & $\square$ & Partial \\
\hline Christersson et al 2015 & $\checkmark \bullet \square \mathscr{H}$ & $\square \bullet$ & Partial \\
\hline Kothe et al 2013 & $\square$ & $\square$ & Partial \\
\hline Lala et al 2013 & - $\square$ & $\square$ & Partial \\
\hline Foley \& Hijazi 2013 & $\square \succ$ & $\bar{\square}$ & Partial \\
\hline Beier et al 2012 & $\square$ & $\square \bullet$ भ & Partial \\
\hline Arnold et al 2011 & $\square \diamond$ H & $\square \mathscr{H}$ & Partial \\
\hline Buyse and Lievens 2011 & $\square \bullet \bullet$ & $\square$ & Partial \\
\hline Buyse et al 2010 & $\square \bullet \bullet$ & $\square$ & Partial \\
\hline Beier et al 2010 & - $\square$ H & $\square$ & $\mathrm{Y}$ \\
\hline Kay et al 2010 & $\bullet$ & $\bullet \quad \square$ & $\mathrm{N}$ \\
\hline Giuliani et al 2007 & Hै & Hै & $\mathrm{N}$ \\
\hline Lynch et al 2006 & $\square$ & $\square$ & Partial \\
\hline Heintze et al 2004 & $\bullet \bullet$ मf & $\square$ & Partial \\
\hline Fenlon et al 2001 & $\diamond \square$ & $\downarrow$ & Partial \\
\hline Röding 2001 & $\square \diamond$ & 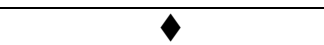 & $\mathrm{N}$ \\
\hline Hoad-Reddick \& Macfarlane 1999 & $\downarrow$ & $\square$ & Partial \\
\hline $\begin{array}{l}\text { Hoad-Reddick \& Macfarlane } \\
\text { 1999a }\end{array}$ & $\square \diamond$ & $\square$ & Partial \\
\hline Röding 1997 & $\square \diamond$ & $\square$ & $\mathrm{N}$ \\
\hline
\end{tabular}

KEY

\begin{tabular}{|l|l|}
\hline $\begin{array}{l}\text { Personal qualities/ } \\
\text { non-academic attributes }\end{array}$ & \\
\hline $\begin{array}{l}\text { Cognitive ability } \\
\text { Academic attainment/ } \\
\text { knowledge }\end{array}$ & $\bullet$ \\
\hline Psychomotor skills & $\square$ \\
\hline
\end{tabular}

This article is protected by copyright. All rights reserved. 
Figure 1- Process of Investigation

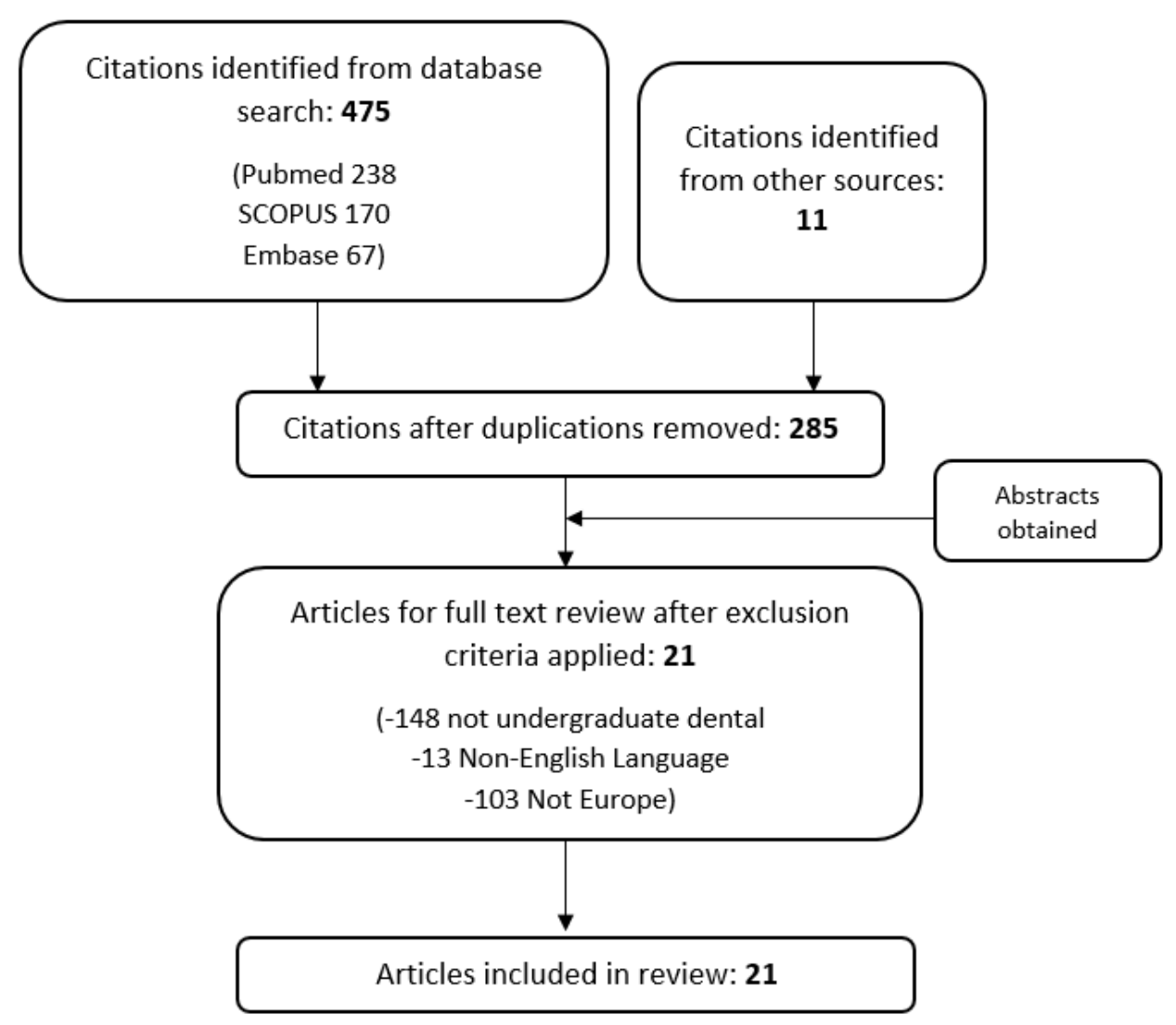

This article is protected by copyright. All rights reserved. 


\section{Box 1 - Context of the study}

The focus is on European studies for two reasons; analogous student populations and comparable workforces upon graduation. Within the EU the majority of dental schools are undergraduate courses, which students enter after completion of high school or equivalent. Although there have recently been the addition of some 'graduate-entry' dental schools in the UK, these differ only in their academic entry criteria when compared to undergraduate schools; university qualifications in specific science related degrees are considered to supersede school qualifications. Students attending graduate entry school are subject to the same funding, fees and learning outcomes and will enter the workplace in the same conditions as their undergraduate counterparts. The dental workforce across the EU is also similar. Dental graduates from European schools can choose to work within any area of the EU due to the current economic policy of free movement between member states. The majority of dental graduates work within privately owned dental practices, with a varying degree of government funding. The candidates applying to dental school throughout the EU should therefore be comparable.

On the other hand, non-EU student populations are subject to a vast array of confounding factors making useful comparisons potentially inconsequential. Factors such as vastly increased cost of study, country specific entrance exams and graduate entry student populations are prevalent in the rest of the world. For example, the average tuition fees in the US is estimated at up to $\$ 46,859$. When combined with additional costs of study, the average US graduate can expect to graduate with over $\$ 200 \mathrm{k}$ worth of debt (ADEA 2010). A recent study of UK final year dental students estimated total debt at $£ 24,734$ (BDA 2014). Student debt is often cited as one of the main contributors to students choosing not to attend university, or failing to complete studies if they do attend (Guardian 2015). The USA also employs the use of an entrance exam into dental college, The Dental Admissions Test (DAT) which is exclusive for use in USA schools. No such universally-used test exists in the EU. Graduate entry schools are also prevalent in the rest of the world. Exclusively graduate-entry contexts, such as the USA, may also influence the nature of the applicant pool (e.g., Gallagher et al 2009).

This article is protected by copyright. All rights reserved. 